DOI https://doi.org/10.36059/978-966-397-116-2/278-294

\title{
THE ROLE OF LEGAL SOCIALIZATION IN THE PROCESS OF FORMATION OF NATIONAL PROTECTION SYSTEM FOR CRITICAL INFRASTRUCTURE IN UKRAINE
}

\section{Shvachka V. Yu.}

\section{INTRODUCTION}

The concept of critical infrastructure is rather new for the world community and it is associated with the strengthening of terrorism and hybrid war threat. Great Britain was the first to speak about the protection of telecommunication, banking and finance sector, water supply, energysaving and other systems, providing life support of the country and its economic growth.

Such problem is urgent for Ukrainian society too. With the adoption of the Concept for the establishment of a state system for critical infrastructure protection by the Cabinet of Ministers of Ukraine in 2017, the formation of a national system for the critical infrastructure protection began in Ukraine.

In order to create a state system for critical infrastructure protection in Ukraine, the Cabinet of Ministers of Ukraine defined the main directions of state authority activities in solving the main problems of the area, in particular, the need to determine the interaction of society and citizens involved in the critical infrastructure protection.

Relations arising in society are governed by historically established traditions, social and legal norms that determine the social and legal status of a person.

A modern law should become an effective regulator of the relations between society and citizens involved in the critical infrastructure protection.

The law in modern society is not merely a "phenomenon in itself", but as an external phenomenon, a powerful regulatory means that requires a person to act in accordance with the requirements of law. In this sense, law is a social regulator, a special measure of freedom, based on the achievements of human civilization and culture development, and serves 
as a criterion for determining the social usefulness (lawfulness) or danger (unlawfulness) of people's behavior and their associations.

Thus, universal human values dominate in the basis of norms of modern law and at the same time, the law is a mean by which they are implemented.

The right, in turn, is vested with priority in social regulation due to its obligatory (imperative) nature, formal definiteness and state safety; it can optimally ensure the normal functioning of a society that is a complex social organism ${ }^{1}$.

According to Alexeyev S.S., mankind has no other way or other means of solving global problems that poses a threat of grave consequences for the human race, but to put modern law in the center of people's life. Only it, the law, can resist a possible catastrophe that threatens mankind in the situation (conditions) of "future anarchy", "liberty", arbitrariness of power, and terrorism".

The modern development of the theory of state and law gives a possibility to affirm that the law is not limited to the role of a normative regulator, but also actively affects the social domain, stimulating social groups, society as a whole to certain forms of behavior and interaction with each other, causing their certain relations with society. Thus, the law ensures the inclusion of individuals and groups in a unified system of social organization. This, in turn, makes it necessary to study not only the basic function of law, namely, the regulation of public relations, but also its specific function, such as legal socialization ${ }^{3}$.

\section{Legal Socialization as a Function of a Modern Law}

For legal socialization, as well as socialization as a whole, not a mechanical reflection of external factors of influence in the person's mind is typical, but a combination of external influence and internal intellectual activity of the persons themselves. In this process, the external, passing through the subjectivity of the personality, is mastered, processed, assimilated, applied and used by a person in own practical activity.

\footnotetext{
1 Львова О.Л. Право і релігія як ціннісно-нормативні системи // Правова держава. Випуск 17. К.:Ін.-т держави і права ім.. В.М. Корецького НАН України, 2006. - С. 73

${ }^{2}$ Алексеев С.С. Линия права. - М.: Статут, 2006 - с. 270.

3 Лапаева В.В. Социология права/ Под. ред. академика РАН д.ю.н., проф. В.С. Нерсесянца. - М., 2000 - c. 191.
} 
The abovementioned aspects of use of the concept of "socialization" in sociology, psychology, political science and jurisprudence is an evidence that in modern socio-psychological and legal science there are different approaches to the definition of legal socialization of the personality. As a rule, the difference between these approaches is resulted from the desire of researchers to focus on the aspect of socialization, which they consider the most significant.

Thus, Kuril'sky-Ovzhin Sh., Arutunyan N.Yu., Zdravomyslova O.M. define legal socialization as an aspect of general socialization, the essence of which is the interiorization of legal norms, the adherence to rules and laws, as well as the formation of orientation on conformance (or deviation $)^{4}$.

Another definition of legal socialization, as the system with the main elements which are, on the one had, the objective conditions of life, the state of law order and legal culture, forming the socio-legal attitude of the personality, and on the other hand, a person alone with their specific social and socio-psychological qualities,-- psychologist Auwyer L.I. gives in his study ${ }^{5}$.

Spiridonov L. I. notes that the legal socialization of the personality is its inclusion in the existing system of public relations, accompanied by their mastering cultural values of any kind, and at the same time, their assimilation of law ${ }^{6}$.

Among the prominent Ukrainian scholars, Holovchenko V.V., Kozyubra M.I., Kopeychikov V.V., Koretsky S.M., Nazarenko Y.V., Onischenko N.M., and Paterylo I.V. studied certain problems of legal socialization of personality.

Thus, the well-known Ukrainian legal theorist Kozyubra M.I. identifies legal socialization and legal education in a "broad sense", defining it as a set of legal influences (both purposeful and, to a certain extent, spontaneous), forming an individual legal consciousness ${ }^{7}$.

In the point of view of other legal theorist, namely Kopeychikov V.V., legal socialization is the process of individual's entering the environment, gradually acquiring legal knowledge by them,

\footnotetext{
${ }^{4}$ Курильски-Овжиен Ш., Арутюнян Н.Ю., Здравомыслова О.М. Образы права в России и Франции. M., 1996. - c. 11.

5 Аувяерт Л.И роль семи и сверстников в правовой социализации несовершеннолетних. Автореф. дис. канд.. психологических наук. М., 1982. - с.4.

${ }^{6}$ Спиридонов Л.И. Теория государства и права. М., 2001 - с.122.

${ }^{7}$ Правове виховання і соціальна активність населення. Київ, 1979. - с.32.
} 
their involvement in society cultural achievements, the processes of cultural achievements embodiment in lawful behavior of the subject, their legal activity, practical transformation of legal relations in the direction of their progressive, humanistic development ${ }^{8}$.

Paterylo I.V. associates the process of legal socialization of the personality with the values existing in society and defines it as the assimilation of legal knowledge by a person during all their life, as well as norms and values of the society to which they belong ${ }^{9}$.

Holovchenko V.V. gives the definition of the legal socialization of the personality with the similar content: legal socialization is the process of assimilation of legal behavior models, legal norms and values by the individual, necessary for the person's successful functioning in a given society ${ }^{10}$.

Onishchenko N.M. considers the legal socialization of the personality not only as a process of assimilating the perception of the society legal values, ideas, experiences, feelings and emotions of people by the subjects, but also as the implementation of legal evaluations, norms and behavior models ${ }^{11}$.

Despite such diversity in the scientific literature of legal socialization definitions, all of them can be conventionally divided into three groups.

Arutunyan N.Yu., Zdravomyslova O.M., Kurilsky-Ovzhien Sh. are the representatives of the first approach in defining the concept of "legal socialization" "12 that is based on the fact that society is considered as a subject of socialization, and an individual as its object. Under socialization in this case we understand the person's entering the system of social-legal relations, involving them in the existing forms of activity. This person's entering the system of social and legal relations is carried out with the help of institutes and agents of legal socialization, through which the society forms the certain qualities in person that are necessary for them to exist in this society further.

So, in this approach the representatives interpret legal socialization as the education of respect for the law in a person, obedience in order to

\footnotetext{
8 Загальна теорія держави і права. Навчальний посібник. За ред. В.В. Копєйчикова. К., 1998 - с. 140.

9 Патерило I.В. Право як ціннісна категорія. Дисертація на здобуття наукового ступеню кандидата c. 33 .

${ }^{10}$ Головченко В.В. Право в житті людини (статті). - К.: Оріони, 2005. - с. 235.

${ }^{11}$ Методика правової освіти: Навчально-методичний посібник. - К.:Атака - Н, 2005. - с. 3.

12 Курильски-Овжиен Ш., Арутюнян Н.Ю., Здравомыслова О.М. Образы права в России и Франции. М., 1996. - с. 11.
} 
achieve person's conformism in relation to the legal system of society, that is, full integration of the person in the ruling legal system of society. This approach is characterized by complete neglect of the person's individuality and their natural activity.

The representatives of the second approach (Holovchenko V.V., Paterylo I.V. Onishchenko N.M. ${ }^{13}$ have an opposite point of view and consider an individual as a subject of legal socialization, but not society.

In their opinion, in the process of legal socialization, the individual assimilates and acquires certain qualities by which they adapt to the existing conditions of legal reality. The uniting element of the approach supporters is their common methodological principles, leading to a unified view of the legal socialization process, as adaptation of the individual to the conditions of environment in order to further its change. Thus, the subject, namely, an active part of legal socialization in this case, is an individual who mobilizes the possibilities of law and uses them to change the environment.

According to the representatives of the third approach (Kopeychikov V.V., Kudriavtsev V.M., Kazimirchiuk V.P., Onishchenko N.M.) $)^{14}$, such opposition in the definition of "legal socialization" concept is not appropriate. Since legal socialization is a two-sided process of interaction between an individual and society in which both parties are active. An individual, as an object of legal socialization, is not deprived of legal activity; moreover, they can choose for themselves the main directions of this process, thus being both an object and a subject of legal socialization. In the process of legal socialization, the individual perceives external conditions of influence selectively. Thus, external (objective) conditions determine human behavior only to the extent that it relates to the internal (subjective) conditions formed as a result of the process of legal socialization.

Thus, in the process of legal socialization, not only society contributes to the formation of the personality, but also the personality, entering the system of public-legal relations, actively affects society.

\footnotetext{
${ }^{13}$ Спиридонов Л.И. Теория государства и права. М., 2001 - с. 122

Патерило І.В. Право як ціннісна категорія. Дисертація на здобуття наукового ступеню кандидата - с. 33.

Головченко В.В. Право в житті людини (статті). - К.: Оріони, 2005. - с. 235.

14 Загальна теорія держави і права. Навчальний посібник. За ред. В.В. Копєйчикова. К., 1998 - с. 140.

Кудрявцев В.Н., Казимирчук В.П. Современная социлогия права. М., 1995 - с. 102.

Методика правової освіти: Навчально-методичний посібник. - К.: Атака - Н, 2005. - с. 3.
} 
Such a point of view is adhered by well-known legal scholars such as Kudriavtsev V.M. and Kazimirchiuk V.P. noting that socialization (including legal socialization) includes, on the one hand, the deliberate influence of social conditions, various social institutions on a person with a view of involving them in the system of concepts, evaluations, ideas, social norms and other cultural values adopted in society, on the other social activity of the person in the process of socialization, as well as the formation of the personality.

A person, acting in a social environment, changes, improves it and at the same time changes own essence, forms new qualities and properties in themselves. Thus, a person in the process of socialization (including legal socialization) acts as the object and subject, affecting the outside world and the inner world, namely, spiritual ${ }^{15}$.

According to author's opinion, such definition of socialization process is the most complete. Moreover, socialization definition, including legal socialization, as a two-sided process, does not contradict fundamental philosophic and sociological theories of G. Tarde T. Parsons.

Thus, the legal socialization of the personality should be understood as the process of forming a personality with an appropriate level of legal consciousness, which manifests itself in involving them to the system of society legal values, assimilating this system by them and in the return socio-legal activities of the personality aimed at correcting social values.

It is the level of legal consciousness of a personality that determines the nature of their behavior and the degree of socio-legal activity.

According to Oksamytny V.V., the socio-legal activity of the personality is the highest level of lawful behavior, reflected in the socially useful activities in the legal field, approved by state and society. This is primarily an initiative behavior. Socio-legal activity is determined by a high level of legal consciousness, a deep legal conviction, a formed independency, a conscious willingness to use the opportunity provided by law, be creatively guided by them in their daily life ${ }^{16}$.

A number of authors (Holovchenko V.V., Neilip G.I., Nelip M.I.) also include to the characteristics of social and legal activity the following: voluntary performance of legal obligations; concern for raising

\footnotetext{
${ }^{15}$ Кудрявцев В.Н., Казимирчук В.П. Современная социлогия права. М., 1995 - с. 102.

16 Правове виховання і соціальна активність населення. Київ, 1979. - с. 149-152; Міжнародна поліцейська енциклопедія: У 10 т / Відп. Ред.. Ю.І. Римаренко, Я.Ю. Кондратьєв, В.Я. Тацій, Ю.С. Шемшученко. - К.: Концерн «Видавничий Дім «Ін Юре», 2003. - с. 686.
} 
the level of legal knowledge; the desire to take personal part in strengthening the rule of law order; active participation in law enforcement activities; intransigence to violations of the rights and legitimate interests of other citizens; readiness to protect citizens, personal legal interests from criminal encroachments; a principled position on the fulfillment of the law requirements by other persons, etc ${ }^{17}$.

Person's socio-legal activity is based on a high level of their legal culture, an integral part of which is the individual values, that is, the system of their value orientations, which is a criterion for person's behavior.

Value orientations can be defined as the system of material and spiritual welfare, which a person and society recognize as a power over them, defining thoughts, deeds, and interpersonal relations of people ${ }^{18}$.

It should be emphasized that values acquire social content, are realized and affect the consciousness and behavior of people only if they are deeply understood and perceived as value orientations. Otherwise, unrealized value exists independently of individual consciousness as an ideal category, serving as one of the sources of some contradictions between social and individual values, between consciousness and the practical behavior of a person ${ }^{19}$.

Thus, the goal of legal socialization of personality is recognition of law as the main element of the system of person's values, which in turn will ensure effective interaction of society and citizens involved in the critical infrastructure protection.

Legal socialization of the personality has both internal and external meaning. The external meaning of the process of legal socialization manifests itself in the influence of all external objective law-making factors on the personality, which in turn, provides for manifestation and correction of the internal structure of the personality. Formation of a specific type of personality in turn reflects the internal subjective meaning of the process of legal socialization.

\footnotetext{
17 Головченко В.В., Неліп Г.І., Неліп М.І. Правове виховання учнівської молоді: питання методології та методики. - К., 1993 - с. 21.

${ }^{18}$ Права людини: соціально - антропологічний вимір. Колективна монографія. Праці Львівської лабораторії прав людини і громадянина Науково-дослідного інституту державного будівництва та місцевого самоврядування Академії правових наук України. / Редкол.: П.М. Рабинович (голов. ред..) та іню - Серія І. Дослідження та реферати. Випуск 13. - Львів: Світ, 2006. - с.234.

19 Патерило I.В. Право як ціннісна категорія. Дисертація на здобуття наукового ступеню кандидата - с. 24
} 
For the first time, the concept of "internal" and "external" socialization to scientific circulation was introduced by Russian philosopher L.K. Sintsova, who notes that the process of perceiving social norms and values by an individual, the assimilating their social experience - that is, internal socialization. In its process, an active subject is an individual. Under external socialization, one should understand the transfer of social experience from society to the individual, where, on the contrary, society becomes an active subject rather than the individual ${ }^{20}$.

Regardless of active or passive assimilation of socio-legal experience in the process of external legal socialization by the individual, its final result must be the formation of, first of all, active legal position of the personality. It is through daily observance, execution and use of legal norms in their activity, an individual not only cognizes the legal norms, but also forms the appropriate level of their legal consciousness. It is not possible to form an appropriate level of legal consciousness and legal culture of the personality only with the help of external factors of influence. A person is a conscious being that actively and selectively perceives external influence, and not passively adapts to the environment.

Thus, the result of external influence on the personality largely depends on their individual value system. Therefore, only if the person has a desire to perceive existing legal values in society it is possible the to use of external legal-socializing factors of influence effectively, which in turn indicates the important role of the individual's self-consciousness, about their active life position in the process of legal socialization. It is self-consciousness, as a factor of internal socialization, contributes to the legal self-education of the individual and is a prerequisite for the legal socialization of the personality.

External legal-socializing factors and legal self-education of the individual, as an internal legal-socializing factor, should not be considered autonomously and absolutely independently of each other, since they are interrelated and are relatively independent aspects of a single process of legal formation and development of the personality, which provide the social conditionality of their legal formation and development, individual

\footnotetext{
${ }^{20}$ Синцова Л.К. Социализация личности и ее правые формы. Автореф. дисертации на соискание ученой степени канд. филос.наук. Л., 1986. - с.9
} 
activity, which manifests itself in various forms of their practical activity and public relations ${ }^{21}$.

The issues of correlation between external legal-socializing factors and legal self-education of the individual are associated with the problem of dialectical relations in all forms of social and individual activity, the creation of conditions in which the goals of public activities will meet the goals of individual activity.

So, despite the relative independence of the external objective and internal subjective legal-socializing factors of the legal socialization process, they will not be able to function effectively without each other. They are closely interconnected, interdependent and so interwoven with each other that even a slight change in the goals or methods of influencing of one of them simultaneously leads to a change of another, namely, reduces or increases total results of legal socialization of personality.

The possibility of transition of external objective legal-socializing factors into internal subjective ones and vice versa provides an opportunity to consider the process of legal socialization as a two-sided process of assimilating objective external factors of influence and simultaneous reproduction of personality's individual qualities. This, in turn, allows determining the process of legal socialization, involving conscious or subconscious assimilation of social experience, that is, the transition of external objective reality and communication into the inner mental activity of the legal consciousness, as well as in the reproduction of the experience previously acquired in the personality's legal consciousness in the element of reality.

It should also be noted that the formation of the personality with a high level of legal consciousness and legal activity, first of all, depends on the correct definition of the goals of personality's legal socialization, and only after that on the choice of one or another of its kind.

\section{Mechanisms of Legal Socialization of Personality}

The process of legal socialization of the personality can be understood only if it is studied in relations between the personality and social conditions of their life, public relations, the activity of this personality, aimed at changing the social environment and own self, personal ideas, views and actions.

\footnotetext{
${ }^{21}$ Галинайтите Ю. В. Правовая социализация рабочей молодежи: проблемы и решения. Автореферат дисертации на соискание ученой степени доктора юридических наук. - Москва, 1998. - с. 16
} 
The existence of a real legal socialization process and personality's activity beyond the boundaries of public relations is impossible, as well as the existence of social relations outside the real life and communication of people. Thus, one can not imagine the process of legal socialization of the personality beyond the real socio-economic, political, cultural, legal and other social relations and communication, which is the basis of various types of human activity.

Public relations are not abstract relationships between people. This is an interpersonal communication, a constant process of mutual influence of people on each other, the confrontation of their needs and interests, the comparison of views and beliefs, the exchange of experience, as well as the results of activity, objectively embodied in material and spiritual culture, the implementation of mutual stimulation, activity control and correction. In communication rational, emotional and volitional mutual influence and interaction of people are carried out; a unity of attitudes and views is manifested and formed, the transfer and learning of habits, style of behavior, lifestyle is carried out, solidarity and unity arise, characterizing group and collective activities ${ }^{22}$.

The public relations have a significant influence on the legal formation of the personality that have developed in society and reflect certain historical conditions of its formation. Each society has its own history, its logic of cultural, social, political and economic functioning.

Relations that arise in society are governed by historically established traditions, social and legal norms determining person's social and legal status.

One of the main factors determining the process of legal socialization of personality is the nature of relations between a person and society, and society and the state. The definition of the main tasks of legal socialization of the personality depends exactly from the person's place and role in the system of socio-legal relations. The presence of contradictions between subjectively planned, albeit the most humane goals and objectively existing public relations will necessarily lead to the negative consequences of the legal socialization process.

Legal socialization of personality is a specific historical phenomenon. Its meaning, purpose and stages are historical in nature and are determined by the socio-economic and political structure of society. That is why, in the process of legal socialization, not any abstract social legal

${ }^{22}$ Москаленко В.В. Социализация личности. К., 1986 - с. 23 
qualities of the person are formed, but specific historical features of the personality necessary for them in daily live in a particular society.

Ignoring socio-historical conditions in the process of choosing ways and means of legal socialization of the personality may negatively affect its outcome. In addition, when choosing the means of legal socialization it is necessary to take into account the individual features of the object.

Therefore, the means of purposeful legal socialization, preferred in the transitional periods of state development, should be applied taking into account the socio-historical conditions of the society existence, as well as individual features of the personality, determining its selectivity in relation to the means of influence.

Legal socialization, being a specific process of formation of a socially active personality with a high level of legal consciousness and legal culture, as a full member of society, has its own internal structure and consists of certain stages.

The first stage of legal socialization of the personality is their social and legal adaptation, which involves adapting a person to the socio-legal conditions, role functions and legal norms inherent in the environment of their existence. Thus, in the process of social and legal adaptation, the person agrees their opportunities and needs with the actual situation in the surrounding environment.

The process of social and legal adaptation of the personality is particularly difficult in transitional periods of society development, since the legal consciousness of middle aged and elderly people who make up a great share of the population, is oriented to the legal system of the past. This, in turn, is explained the fact that it is much more difficult to adapt to new socio-legal conditions of reality for older people than for young people.

It is social and legal adaptation that is a mandatory stage of the person's entry into the system of social and legal relations of reality.

The second stage in the process of legal socialization of the personality is interiorization, that is, the process of understanding of the legal traditions, legal culture and legal norms prevailing in this society that have been acquired by a person, which, as a result, either become a part of their internal convictions, or may be rejected by a person. 
In order to become a real stimulus and regulator of lawful behavior, legal knowledge must transfer into value orientations, get an emotional coloring, and become internal conviction ${ }^{23}$.

In the process of interiorization, the personality gives own evaluation of the categories, values and legal norms existing in society in accordance with the level of their legal consciousness and legal culture, which, in turn, reflect the system of social values objectively existing in a given society and subjectively reflected in individual behavior.

The result of interiorization of a personality is the formation of a certain type of legal thinking, typical of a particular person's system of values, that is, the formation of individuality of each personality.

The third stage of legal socialization of personality is exteriorization, resulted in the person's return external influence on the society. Having adapted to the socio-legal conditions of own existence, by assimilating legal norms, legal traditions, legal culture of society, including them in their own internal system of socio-legal values, the personality as an active subject with the proper level of legal culture and legal consciousness carries the reverse process of the society formation.

Therefore, the stages of the legal socialization process mentioned above can be defined as the structural components of its mechanism.

Thus, the mechanism of legal socialization of the personality consists of three components, namely:

- Socio-legal adaptation in which the person adapts to the existing legal norms, traditions, etc;

- Interiorization, that is, the process of assimilation of moral values, guidelines and legal norms, including them in the inner world of personality;

- Exteriorization, in the process of which a personality effects the environment through the "implementation into life" of views, ideas, beliefs of moral, legal and social values acquired in the process of sociolegal adaptation and redefined in accordance with individual characteristics and involved in the own internal world in the process of interiorization in order to change society as a whole.

The mechanism of legal socialization, in turn, is associated with the activity of legal and social institutions, special means of legal influence and control. At all stages of legal socialization, society, through its

\footnotetext{
23 Шиханцев Г.Г. Юридическая психология. / Отв. Ред.. д.ю.н., проф.. В.А. Томсинов.- М.: Издательство «Зерцало», 2000 - с. 30;
} 
institutions and agents, directly affects the personality. As a result, the transfer of relevant experience and knowledge, skills and abilities, system values and norms from generation to generation take place. Thus, legal socialization can become an effective means of forming the National System for the critical infrastructure protection of the country.

The concepts of "agent" and "institution" of socialization often merge into a single concept. However, distinguishing of legal socialization agents and institutions is a result of the level of their connection with the object of legal socialization.

Thus, an institution can be defined as a socio-political association, a social group where a person as well as a state body, institution, nongovernmental organizations is a member, exercising influence over it as subjects of legal socialization.

In this case, the subject, through which the transfer of legal values is carried out directly, will act as an agent of legal socialization, whereas a person, to whom the actions of the institutions and agents are directed, will be an object to legal socialization.

Thus, institutes of legal socialization of the personality introduce a certain system of legal values through their agents, which, in turn, provide a direct link of society with the object of legal socialization - the person themselves.

To the main institutes of legal socialization S. M. Koretsky involves: family, school, electronic mass media and communications, the closest social environment (groups of leisure activities, production or training staff) ${ }^{24}$.

Thus, the institutions of legal socialization are the state represented by bodies of state power, higher educational establishments, labor groups, various associations of citizens, schools, pre-school establishments, families, etc., and its agents, that is, direct participants in the process of legal socialization of personality, namely, parents, relatives, friends, teachers, officials, colleagues at work, etc. It is through the activities of institutes and agents of legal socialization that the influence of external factors on the personality is exercised. Effectiveness of each of them depends on many factors, and, above all, on the level of person's legal consciousness, age, state and the intensity of their inclusion in the sociolegal processes of society. The state, in turn, as one of the main institutes

\footnotetext{
24 Корецький С.М. Кримінологічна характеристика девіантної поведінки неповнолітніх. Автореферат дисертації на здобуття наукового ступеню кандидата юридичних наук. - К., 2003 - с. 13.
} 
of legal socialization of the personality, should ensure the harmonious interaction of all other institutions and agents.

In our time, this fact becomes particularly evident. Substantial changes in the economic, political, legal and other domains of public life have caused the corresponding changes in the system of legal values, ideas and views.

The formation of a national system for the critical infrastructure protection in Ukraine requires additional legal socialization of the personality, as a result of which new social values should become the values of each person.

According to O.L. Lvova, the discrepancies between the social and individual values of the personality are the huge grounds for the fact that even the most justified and legal law can remain only a great proclamation, if its value of meaning and purpose does not coincide with the internal convictions of the person, do not come to life in their consciousness. That is why the great attention of both state bodies that create and apply law and scientists studying state-legal phenomena should be given to "breaking" of old, outdated and inactive stereotypes that have taken place since the Soviet era when a person existed for the state. If this does not happen, then all the efforts of Ukraine to achieve European standards will be useless. It is necessary to change the style of thinking and views, to re-evaluate priorities in own consciousness before trying to understand and accept new, effective and truly valuable standards dominating in the whole civilized world ${ }^{25}$.

Thus, the quantitative indicator of person's legal values acquired in a certain period of life gains a qualitative value and transfers into their legal consciousness.

Considering the concept and meaning of legal socialization of the personality and defining its mechanism, it can be affirmed that the formation of a socially active personality takes place under the influence of all elements of the legal system. Such influence is carried out independently of the will of the persons themselves, the state bodies taking the relevant decisions, other subjects of law, since the state of the legal system as well as the functioning of its elements is a reflection of individual legal consciousness.

\footnotetext{
25 Львова О.Л. Право живе та діюче (про ціннісні орієнтації права) // Часопис Київського університету права, № 1, 2007 р. - с.
} 


\section{CONCLUSIONS}

To create a state system for protecting critical infrastructure in Ukraine there is a need to determine the interaction between society and citizens involved in the critical infrastructure protection.

A modern law is not limited to the role of a normative regulator, but also actively affects the social field, motivating social groups, society as a whole to certain forms of behavior and interaction with each other, causing their certain connections with society. In this way, the law ensures the inclusion of individuals and groups in a single system of social organization. This, in turn, makes it necessary to study not only the basic function of law such as regulation of public relations, but also its specific function, such as legal socialization.

The legal socialization of the personality should be understood as the process of forming a personality with an appropriate level of legal consciousness, which manifests itself in involving them in the system of society legal values, assimilating this system by them and in the reverse social and legal activities of the personality aimed at correcting social values.

It is the level of legal consciousness of the personality that defines the nature of their behavior and the level of socio-legal activity.

In the process of legal socialization, the personality is influenced by both internal and external factors. Not taking into account the relevant independence of external objective factors and internal subjective legalsocializing factor, they can not function without each other effectively. They are interrelated, interconnected and interwoven in such a way that a minor change of purposes or methods of influence on one of them leads immediately to the change of the other, in particular, reduces or increases the general results of personality's legal socialization.

One of the main factors determining the process of legal socialization of personality is the nature of relations between a person and society, and society and the state. The definition of the main tasks of legal socialization of the personality depends exactly from the person's place and role in the system of socio-legal relations. The presence of contradictions between subjectively planned, albeit the most humane goals and objectively existing public relations will necessarily lead to the negative consequences of the legal socialization process.

That is why, forming a critical infrastructure protection system in Ukraine, one should keep in mind such an effective function of modern law as legal socialization of the personality, which with a correct 
definition of the purpose and means of its realization, will provide for an effective interaction of society, state and citizens involved in the critical infrastructure protection.

\section{SUMMARY}

The concept, meaning and essence of legal socialization of the personality are considered. It is determined that the legal socialization of the personality should be understood as the process of formation of the personality with an appropriate level of legal consciousness, which manifests itself in involving them in the system of legal values of society, assimilating this system by them and in the reverse social and legal activities of the personality aimed at correcting social values.

The main factors influencing the process of socialization under the modern conditions of Ukrainian society development are considered.

The mechanism of legal socialization is studied. Its main elements are determined.

The role of legal socialization of the personality in forming the critical infrastructure protection system in Ukraine, which can become an effective means of ensuring effective interaction of the society, the state and citizens, involved in the critical infrastructure protection, is formulated.

\section{REFERENCES}

1. Алексеев С.С. Линия права. - М.: Статут, 2006.

2. Аувяерт Л.И роль семи и сверстников в правовой социализации несовершеннолетних. Автореф. дис. канд.. психологических наук. М., 1982.

3. Галинайтите Ю. В. Правовая социализация рабочей молодежи: проблемы и решения. Автореферат дисертации на соискание ученой степени доктора юридических наук. - Москва, 1998.

4. Головченко В.В. Право в житті людини (статті). - К.: Оріони, 2005 .

5. Головченко В.В., Неліп Г.І., Неліп М.І. Правове виховання учнівської молоді: питання методології та методики. - К., 1993.

6. Загальна теорія держави і права. Навчальний посібник. За ред. В.В. Копєйчикова. К., 1998.

7. Корецький С.М. Кримінологічна характеристика девіантної поведінки неповнолітніх. / Автореферат дисертації на здобуття наукового ступеню кандидата юридичних наук. - К., 2003. 
8. Кудрявцев В.Н., Казимирчук В.П. Современная социлогия права. М., 1995.

9. Курильски-Овжиен Ш., Арутюнян Н.Ю., Здравомыслова О.М. Образы права в России и Франции. М., 1996.

10. Лапаева В.В. Социология права/ Под. ред. академика РАН д.ю.н., проф. В.С. Нерсесянца. - М., 2000.

11. Львова О.Л. Право живе та діюче (про ціннісні орієнтації права) // Часопис Київського університету права, № 1, 2007 p.

12. Львова О.Л. Право і релігія як ціннісно-нормативні системи // Правова держава. Випуск 17. - К.:Ін.-т держави і права ім. В.М. Корецького НАН України, 2006.

13. Методика правової освіти: Навчально-методичний посібник. К.: Атака - Н, 2005.

14. Москаленко В.В. Социализация личности. К., 1986.

15. Патерило I.В. Право як ціннісна категорія. Дисертація на здобуття наукового ступеню кандидата.

16. Права людини: соціально - антропологічний вимір. Колективна монографія. Праці Львівської лабораторії прав людини і громадянина Науково-дослідного інституту державного будівництва та місцевого самоврядування Академії правових наук України. / Редкол.: П.М. Рабинович (голов. ред..) та іню - Серія І. Дослідження та реферати. Випуск 13. - Львів: Світ, 2006.

17. Правове виховання і соціальна активність населення. Київ, 1979.

18. Міжнародна поліцейська енциклопедія: У 10 т / Відп. ред. Ю.І. Римаренко, Я.Ю. Кондратьєв, В.Я. Тацій, Ю.С. Шемшученко. К.: Концерн «Видавничий Дім «Ін Юре», 2003.

19. Синцова Л.К. Социализация личности и ее правые формы. Автореф. дисертации на соискание ученой степени канд. филос. наук. Л., 1986.

20. Спиридонов Л.И. Теория государства и права. М., 2001.

21. Шиханцев Г.Г. Юридическая психология. / Отв. Ред.. д.ю.н., проф.. В.А. Томсинов.- М.: Издательство «Зерцало», 2000.

\section{Information about the author: Shvachka V. Yu. Candidate of Judicial Sciences, Assistant Professor}

